\title{
Conceptualizing Technoscience in a Reasonable, Constructivist Way
}

\author{
Ewa Bińczyk, Toruń
}

It is personally satisfying for me to take part in the discussion about reality and construction by presenting a specific, "reasonable" version of constructivism. Of course, this version is the most promising one, at least in my opinion. Let me admit from the beginning that it is widely inspired by Bruno Latour's actor-network theory and also other results of the so-called STS - science and technology studies.

One of characteristic, troublesome areas of the discussion about constructivism (and reality) is the special status of scientific knowledge, often legitimized by a "miraculous", practical success of technology. Let me underline that in my paper I will picture science and technology as practically successful, underdetermined and historically institutionalized at the same time.

Moreover, as I believe, constructivist position turns out to be especially convenient and useful, when we analyze the role of scientific discoveries and technological innovations in the globalized world. The parameters of our reality (understood as social, normative, symbolic and also material/physical context) are constantly transformed on such a large scale that only dynamic, relational and anti-essentialist theoretical frameworks prove to be able to grasp these processes. Therefore, the last purpose of my presentation is to argue that a reasonably projected constructivism is a theoretical background needed to carefully rethink the most important political problems of the risk society today.

The conceptualization presented here can rightly be labeled as pragmatic or Darwinian. I define science and technology similarly in this perspective, as two spheres of a historical, collective practice of controlling and predicting isolated phenomena (Richard Rorty defines scientific activity in a parallel way). Scientific and technological efforts aim at "coping" 
with reality or domesticating the environment. I will consider science in this paper as a collective undertaking in its whole complexity, not only in its intellectual dimension - not only as a set of theories (this would be a reductionist decision, considering only one kind of scientific results).

Conceiving cognition as, first of all, effective action, seems theoretically valuable, as I think. This is openly assumed regarding cognition of all organisms, not only human beings, within such biologically inspired fields, as radical constructivism or enactivism. Ernst von Glasersfeld, Niklas Luhmann or Francisco Varela for instance study the dynamic processes of knowing, emerging from the multiple interactions of the organism with the environment. They define the function of cognition not as representation, but as viability (resulting in adequate behavior or fitting).

Unfortunately, those two fields analyze cognition mainly in its individual context. Yet human cognitive activity is a collective, multidimensional phenomenon. It is enriched through human coordination and language, through the use of instruments, laboratories and artificial systems, for instance informational technologies, like writing. Therefore, to describe human cognition adequately, such theories as enactivism or radical constructivism must be supplemented.

I accept some form of a "flat" realism, just to state that human practices (also cognitive) take place in the context of a certain environment. Ludwik Fleck articulated a similar position, when he wrote "I use the word "reality" only for grammatical reasons, in sentences about cognitive activities" (Fleck 1986, 196, trans. E.B.). Even Bruno Latour answers affirmatively to the question "Do you believe in reality?" (Latour 1999, 1-23).

Nevertheless, this realism is epistemologically trivial, being supplemented by a decisive anti-representationalism. The decision to avoid excessive epistemological, representational claims seems justified, especially if we remember the unsuccessful philosophical trials to indicate universal, rational algorithms of scientific method or to ensure the privileged epistemological status of scientific (or any) knowledge.

Thereby, "reality" in the model presented here is assumed only as an epistemically elusive factor, playing no decisive role. It goes without saying that the underdetermination thesis is a crucial element of my conceptualization. The article assumes that both theories and optimal practical 
solutions are underdetermined by empirical evidences or a material resistance.

What is interesting, radical constructivists mentioned above use similar solution. They assume explicitly some kind of the non-arbitrariness of knowledge. It is understood by Luhmann for example as the evolutionarily-controlled selectivity of the process of a cognitive system's constitution and transformation (Luhmann 1990, 77). Yet, the environment is so rich that it is possible to construct a lot of epistemic alternatives. In effect, human knowledge is underdetermined, it cannot claim uniqueness: no matter how viable the cognitive solution might seem, it can never be regarded as the only possible one.

Several statements concerning the term "construction" should be added at this point. "Construction" turned out to be a very dangerous metaphor - we observed many examples of misunderstandings and erroneous interpretations in this respect (cf. Hacking 2000, 1-62). First of all, construction is never freely done by an individual actor. Constructing is a collective work, historically rooted. In this point the term „construction” proves to be close to the classic sociological term "institutionalization" or even to the term "stabilization".

Constructing is also for me a multidimensional undertaking - not only social and symbolic, but also material. Let us consider such contemporary examples of constructed entities, as the ozone hole, frozen embryos, data banks, hybrid corn, experts systems or psychotropic drugs (cf. Latour 1993, 49-50). The first of them, the ozone hole, is not only a physical phenomenon, for it is caused by the human intervention, made visible by human scientific practices and instruments, and becomes a subject of controversies and concern through documents, conferences and legal instruments. Many layers are intertwined here: normative, material, social and symbolic.

Moreover, as the examples above illustrate, the effects of constructing are not artificial, false or merely textual - they can be objective and real. Every potentiality that is domesticated through collective human practice can be called "constructed". The domestication has both cognitive and practical dimension, it took place for instance in the Neolithic Revolution when breeding and agriculture was invented, supported by a new form of knowledge. The other example is coping with bacterias through the invention of hygienic procedures, vaccines and antibiotics that emerged together 
with specific biological theories generating new ontological claims (Latour 1988).

The important limitations of constructing are previous constructions. New conceptual structures or practical solutions should be compatible with those already existing. In the history of technoscience we observed that alternative solutions or theories had been cut off or ignored.

$* * *$

Nowadays, scientific and technological efforts constitute the innovative "core" of culture, where systematic and professional constructing takes place. It became possible especially due to the institutionalization of an experimental method in a certain historical moment. If we focus on an empirical, laboratory-centered dimension of science (as Science and Technology Studies did), we perceive mainly the successful practices of controlling and predicting. Because they are so strongly dependent on instruments and analogical to technological efforts, Bruno Latour, for instance, proposes to use the uniform term "technoscience" (Latour 1987). This term stresses that there is no significant difference between those two fields: while solving both theoretical and practical problems, scientists try to replicate experiments and engineers work to create working machines.

Technoscience is funded on its internal systematic character. It is also institutionally rooted in laboratories. In a powerful, innovative context of laboratory it becomes possible to make errors without consequences, to repeat trials, to negotiate hypotheses looking for the best explanations or solutions (Latour 1983). In laboratories, scientists and engineers professionally domesticate the environment. They construct entities, build connections, establish relations, while minimizing costs and disturbances. The work in laboratory is a mundane question of guessing, trying as much as possible to manipulate ordinary objects, models, graphs, tables, maps, materials and samples.

Of course, technoscientific work is acted out in the physical, material context. Interventions in material context in laboratories give voice to facts and codetermine the content of scientific knowledge. As Latour puts it: "Objects that exist simply as objects, detached from a collective life, are unknown, buried in the ground" (Latour 1999, 193). Scientific knowledge 
is always underdetermined and embodied in complex processes of laboratory transformations. Microorganisms are only visible, when we prepare them, by staining with aniline dye. Reality is prepared and also stabilized by such instruments, like radio sonograms, microscopes, computer tomographs, ultrasound scanners. Nevertheless, we cannot unambiguously determine the material factor (understood as the innocent, empirical ,input”, absolutely independent from human procedures, assumptions, categorizations, theories, interventions, etc.).

The stability of content in the history of science can be understood here, if we take into consideration that it is maintained exactly by laboratory standardized methods and instrumental procedures. Scientific equipment is much more stable than theories, paradigms or even established facts.

Spectacular practical success of science can be described and explicated from this point of view as well. It derives from large efforts to replicate procedures, standardize criteria and stabilize technoscientific achievements. Selected solutions invented in laboratories are next "capitalized" in artifacts, larger technological systems and material infrastructures incorporated into reality outside laboratory. "Science in action" transforms the whole context of human practice (Latour 1987).

Such diagnoses of the modern society, as for example Ulrich Beck`s, Anthony Giddens`s and also Latour's view suggest that scientific and technological interventions, incorporated into the industry, reshape society on a large scale and produce many unintended side effects. Unexpected, dangerous consequences are visible in many distant fields: material, environmental, institutional, political, economic and normative. Technoscientific dynamics generates currently new forms of risk and destabilization.

I will use the terms "risk" in a manner close to the way in which Beck uses it (Beck 1992). Risk is here a probability of some dangerous, unpredictable side effects of an innovation. Risk is always a social construct in many dimensions (in spite of being really harmful, like chemical pollution). It must be recognized, described, articulated, estimated by its spokespersons. The multidimensional construction of risk has also a nor- 
mative background. It is impossible to objectively define "dangerousness," without taking into consideration certain axiological preferences. Moreover, there are no effective, unproblematic methods to calculate risks.

We must agree that human practices, interferences and constant decision processes permanently transform the border parameters of reality. From the historical moment in which the professional laboratory has been invented, socializing new potentialities, i.e. incorporating them into collective has taken a very intensive, accelerated form. Technoscience and industry simply introduce too many deep changes on an extensive scale. Global context of mutual interdependence, feedback effects, and reciprocal interactions only intensifies this situation.

In regard to the hybrid nature of so many entities incorporated into reality today, we need a new, non-anthropocentric paradigm to describe it. This is why (among other reasons) Latour does not speak about society anymore. He uses the term "collective" instead, defining the associations of humans and non-humans. The extent of current ecological, medical, biotechnological or genetic interventions make this terminological decision quite reasonable.

According to Beck our society enters into a phase of a "reflexive modernity". We live in the era of catastrophes, openly discussed controversies, changing role of experts, and the emerging phenomena of the counterexpertise. There are also important political changes. Politicians are forced to make quick decisions in the conditions of uncertainty or a partial recognition. The modern society envisages also growing political fights over risk-defining positions.

As a result, many assumptions, taken for granted until now, demand serious problematization. Among them are the Enlightenment idea of progress (defined as inevitable), the ideological fundaments of a capitalist system, the premise that knowledge is a nonproblematic good and technology is a beneficial, innocent instrument.

"Reflexive modernity" needs to question also those values that constitute a market infrastructure (such as profit, constant consumption, or production demands). The uncritical attitudes towards them caused among other a high level of the commercialization of science. It becomes painfully visible for example in biomedical research, especially in the context of patenting embryos, human genes and new organisms. 
Despite the fact that it seems almost incredible, we need to take into account today that the majority of products should never be produced! It is postulated regarding the amount of pollution that production of some objects requires; regarding the danger some products pose (like weapon or certain chemicals); regarding the triviality of many needs created by the advertising practices, targeting also children.

In conclusion let me simply enumerate selected theses resulting from the problems discussed in the article.

1) A public open debate about innovations must be created, before they are introduced into society. Directions and the very reasonableness of technoscientific research should not be discussed post factum, when it is usually too late. This is how a systematic helplessness is projected.

2) Not only experts, representatives of corporations or government, but also sociologists, ethicians and lay people afflicted by a change, should be invited to the discussion. At this point paternalism of state and experts should be avoided.

3) We should stop analyzing the relation between technoscience and society in terms of the impact of one independent sphere on another, or in terms of isolated, innocent discoveries/gadgets. We observe rather deep and global interconnections between heterogeneous elements. Introducing an innovation in one sphere may cause a serious unexpected effect in another, distant domain.

4) No matter how difficult such project may seem, we should try to create global, institutional, systemic monitoring of the industry and technoscientific development. We need intellectuals to moralize those issues, problematize them and build a global macroethics which is still in its initial stage. 


\section{Literature}

Beck, Ulrich 1992: Risk Society: Towards a New Modernity. New Delhi: SAGE.

Fleck, Ludwik 1986: Powstanie i rozwój faktu naukowego. Wprowadzenie do nauki o stylu myślowym i kolektywie myślowym. Lublin: Wydawnictwo Lubelskie.

Hacking, Ian 2000: The Social Construction of What? Cambridge, MA: Harvard University Press.

Latour, Bruno 1983: Give Me a Laboratory and I will Raise the World. In: KnorrCetina, Karin / Mulkay, Michael (eds.): Science Observed: Perspectives on the Social Study of Science. London: SAGE Publications, 141-170.

Latour, Bruno 1987: Science in Action: How to Follow Scientists and Engineers Through Society. Cambridge, MA: Harvard University Press.

Latour, Bruno 1988: The Pasteurization of France. Cambridge, MA: Harvard University Press.

Latour, Bruno 1999: Pandora 's Hope. Essays on the Reality of Science Studies. Cambridge, MA: Harvard University Press.

Luhmann, Niklas 1990: "The Cognitive Program of Constructivism and a Reality that Remains Unknown”. In: Krohn, Wolfgang / Küppers, Günter / Novotny, Helga (eds.) Selforganization. Portrait of a Scientific Revolution. Dordrecht: Kluwer, 64-85. 